\title{
GC wt Allele
}

National Cancer Institute

\section{Source}

National Cancer Institute. GC wt Allele. NCI Thesaurus. Code C52279.

Human GC wild-type allele is located within $4 q 12-q 13$ and is approximately $42 \mathrm{~kb}$ in length. This allele, which encodes vitamin D-binding protein, is involved in the transport of vitamin $\mathrm{D}$ and its metabolites to targeted tissues. 